\title{
Causative Factor of Accidents in Commercial Buildings of Bharatpur Metropolitan City
}

\author{
Er. Rochak Adhakari ${ }^{1}$, Anjay Kumar Mishra ${ }^{2 *}$, Er. Khem Raj Joshi ${ }^{3}$ \\ ${ }^{1}$ Master's Research Scholar, United Technical College affiliated to Pokhara University and Project Manager, Chitwan Udhyog Sangh-Chitwan Expo \\ Center, Bharatpur, Nepal \\ ${ }^{2}$ Associate Professor and Research Director, Madan Bhandari Memorial Academy Nepal and Pokhara University Urlabari 3, Morang, Nepal \\ ${ }^{3}$ Registrar, Nepal Engineering Council, Kathmandu, Nepal
}

DOI: $10.36348 /$ sjee.2020.v04i07.001

| Received: 24.08.2020 | Accepted: 01.09.2020 | Published: 09.09.2020

*Corresponding author: Anjay Kumar Mishra

Abstract

Construction is a highly demanded for rapid development. In Chitwan, recently, large construction projects are ongoing that includes commercial buildings in majority. However, Construction industry is taken as the dangerous and dirty industries. Like every construction project, commercial building projects also involve different factors of Accident. Safety aspect is less concerned on the construction site. The objective of the paper is to assess the causative factors accidents in construction projects of commercial Building in Bharatpur. It will be significant to the construction practitioners and its stakeholders. It helps them to avoid accidents by maintaining safety requirement in their construction project and help them implement good provisions of safety adopted by other companies. Site visit of the Housing and interview were conducted after extensive literature review to list all the possible factors for questionnaire preparation. Questionnaires survey was conducted to all the consultant and contractor team working in the Area. Relative Importance Index was used to rank the major accident causation factor. The causation factor attribute to organizational level were identified as major one. No compliance to governmental safety rules and regulation, Workers Negligent in wearing personal protection items, Lack of working space and site layout, Condition of equipment, Workers was rushing to the work and Appropriate Personal Safety procedures were not specified were majour factors of accidents. The housing safety management in the project was inferior to the anticipated codes and byelaws. Some of the accident causation factor from the literature review also coincides with the risk and hazards in the housing construction.

Keywords: Organizational, Workers, Rules, Relative Importance Index, Accident.

Copyright @ 2020: This is an open-access article distributed under the terms of the Creative Commons Attribution license which permits unrestricted use, distribution, and reproduction in any medium for non-commercial use (NonCommercial, or CC-BY-NC) provided the original author and source are credited.

\section{INTRODUCTION}

Construction safety is the state of being free form any kind of risk and injuries while construction proceeds. It reflects the physical, mental and social well-being of the worker involved in construction [1].

Safety management means the proper arrangement of construction site in order to safeguard the health of construction workers through effective implementation of safety standard and measures. In Nepal, Labor Act 2017, Nepal National Building Code [2] are the institutional documents that specifies the safety requirement of construction site to be properly followed by construction practitioners. Contract document contains the specification for safe working environment. Contractor is made responsible through bid document, to carry on the construction activities ensuring health and safety of the involved workers.
Building construction project in Chitwan district is not an exception. The status of safety management is, however, not the same through every project. Though being commercial building projects; objective of building, location of site, nature of construction materials used, methodology adopted, nature and type of contractor are some factors that makes variation in adopting the safety standard, in practice.

Construction is one of the biggest industries in Nepal. It contributes $11 \%$ of total GDP of the country after agriculture. Construction is considered as the second largest employer of the country utilizing huge Skilled and unskilled labor forces [3]. According to Maskey and Mishra [4], the idle time of skilled and unskilled labor is almost equal with $16.04 \%$ and $16.26 \%$ which shows prospectus of improvement if safety and productivity could be enhanced together. GDP from construction in Nepal increased to 55121 
NPR Million in 2018 from 50595 NPR Million in 2017. GDP from construction in Nepal averaged 36923.28 NPR Million from 2001 until 2018, reaching an all-time high of 55121 NPR Million in 2018 and a record low of 27225.05 NPR Million in 2001 (Trading Economics, https://tradingeconomics.com/nepal/gdp-fromconstruction).

Out of Total industries established in the country, $0.17 \%$ of these industries are construction industries. Currently, 1608 construction companies have been registered in Nepal, where the pattern shows 320 industries added in the fiscal year 2074/075 while 182 were registered in the year 2073 [5]. Huge investment of National budget on infrastructure highlighted the scope of construction industry herein Nepal. Government has allocated the budget on safe drinking water and sanitary, irrigation sector, road infrastructure development, reconstruction of earthquake affected heritages, and other infrastructure sector (MOF Budget Speech 2076/77, 2019).

In Chitwan, recently, large construction projects are ongoing that includes commercial buildings in majority. The project includes Multi Storied resort buildings, Factory Buildings, Exhibition Buildings, Hospitals, Party Venue, and Pharmaceuticals etc. Thus, In Nepal, including Chitwan, this industry is the highly demanding and progressive industry. Despite its importance, the concept $\mathrm{OSH}$ has not been a prior agenda in construction field and still new in Nepal. The higher illiteracy among the workers, lack of the awareness, poor performance or the inattention of the concerned government authorities in implementation of OHS related policies and activities have shadowed these issues. The aim of the paper is to assess the factors of causing Accidents in Commercial Buildings of Bharatpur Metropolitan City.

\section{LITERATURE REVIEW}

In the construction industry, owners, contractors and designers have the obligation to provide a safe site working environment, and their negligence on safety may cause severe accidents and injuries as well as economic loss [6]. A large number of construction accidents are reported and thousands of workers are killed or injured on construction sites each year. As a result, project owners lose large amounts of money and many families suffer from permanent pain.

\section{Common Types of Construction Accidents}

There are many types of construction accidents, and they can be classified by different categories. In terms of severity, a construction accident may or may not cause injuries and life loss, and the economic loss may be small or huge. A construction accident can be rooted in equipment failure, design ignorance, working carelessness, and natural disasters, etc. In addition, based on the locations, there are tunnel accidents, highway construction accidents, and residential building site accidents, to name but a few.

\begin{tabular}{|c|c|c|c|c|c|}
\hline $\begin{array}{l}\text { Classification } \\
\text { Category }\end{array}$ & Labor Type & Project Type & Heavy Equipment & $\begin{array}{l}\text { Building } \\
\text { Component }\end{array}$ & Others \\
\hline $\begin{array}{l}\text { Accidents } \\
\text { Examples }\end{array}$ & $\begin{array}{l}\text { - Painter Accidents } \\
\text { - Plumber Accidents } \\
\text { - Iron Worker } \\
\text { Accidents } \\
\text { - Brick Layer } \\
\text { - Accidents } \\
\text { - Carpenter } \\
\text { - Accidents } \\
\text { - Maintenance } \\
\text { - Uorker Accidents } \\
\text { - Union Worker } \\
\text { - Accidents } \\
\text { Etc. }\end{array}$ & $\begin{array}{l}\text { - Tunnel Accidents } \\
\text { - Excavation } \\
\text { Accidents } \\
\text { - Highway } \\
\text { Construction } \\
\text { Accidents } \\
\text { - Residential } \\
\text { Building Site } \\
\text { Accidents } \\
\text { - Bridge Accidents } \\
\text { - Parking Garage } \\
\text { Collapse } \\
\text { - Demolition } \\
\text { Accidents } \\
\text { - Etc. }\end{array}$ & $\begin{array}{l}\text { - Crane and Truck } \\
\text { Accidents } \\
\text { - Welding } \\
\text { Equipment } \\
\text { Accidents } \\
\text { - Ladder Accidents } \\
\text { - Scaffolding } \\
\text { - Failure } \\
\text { - Elevator Accidents } \\
\text { - Power Tool } \\
\text { Accidents } \\
\text { - Cable and Rope } \\
\text { - Accidents } \\
\text { - Forklift Accidents } \\
\text { - Saw Blade } \\
\text { Accidents } \\
\text { - Etc. }\end{array}$ & $\begin{array}{l}\text { - Ceiling } \\
\text { Collapse } \\
\text { - Wall } \\
\text { Collapse } \\
\text { - Stairs } \\
\text { Failures } \\
\text { - Window } \\
\text { Installation } \\
\text { Failure } \\
\text { - Slab } \\
\text { Failure } \\
\text { - Etc. }\end{array}$ & $\begin{array}{ll}\text { - } & \text { Falling } \\
& \text { Object } \\
& \text { Accidents } \\
\text { - } & \text { Fire and } \\
& \text { Explosions } \\
\text { - } & \text { OSHA } \\
\text { Violations } \\
\text { - } & \text { Etc. }\end{array}$ \\
\hline
\end{tabular}

The most widely known theories of accident causation: Domino theory, Human factors theory, Accident / incident theory, Epidemiological theory, Systems theory, the energy release theory, Combination theory and show on.

\section{Construction Accidents and their Causes}

Research studies have confirmed that the construction industry is one of the most hazardous industries all over the world. In most countries, the rate of accident and injuries prevailing in the industry are higher than what prevail in other industries [7]. Accidents in construction may be attributed to various reasons like nature of roadwork (E.g.: Road works, Water/ wastewater pipeline, Hydropower dam), difficult work site conditions (e.g.: Working in deep trench, hills, highways etc.), safety management, human behavior. The occurrence of accidents in under 
developed countries are high asworkers are generally unskilled or semi-skilled, poorly paid, temporarily employed, top management is not committed to safety program or procedures [8].

Two majors factors that lead to the high number of accidents in construction [9].

a) The industry is highly splintered into a formidable number of very diverging entities having different safety goals in mind.

b) A high rate of temporary workers and turn over with less experienced and untrained workers.

An accident can be defined as unplanned, unexpected occurrence which upset the planned sequence of events and actions resulting in the loss of production, injury to the persons \& damage to the plants and equipment.

\section{Unsafe Conditions}

An unsafe condition is one in which the physical layout of the workplace or work location, and the status of tools, equipment and/or material are in violation of contemporary safety standards [10]. A few examples of unsafe conditions are:

1. Defects of agencies such as rough, sharp, or slippery work, defective equipment, overloaded tools or equipment, defective ladders at site, and improperly constructed scaffolds

2. Dress or apparel hazards such as lack of protective equipment and improper clothing

3. Environmental hazard such as inadequate aisle space, insufficient work space, inadequate ventilation and improper illumination

4. Placement hazard such as inadequately guarded, unguarded, unshielded, or protruding end of reinforcing rods, protruding nails and wire ties , and unshared trenches
These conditions include lack of proper planning, deficient enforcement of safety, and absence of safety equipment, unsafe methods or sequencing, unsafe site condition such as poor housekeeping, broken ladder and structurally deficient work platform.

\section{Unsafe Acts}

An unsafe act may be an act of commission (doing something that is unsafe) or an act of omission (failing to do something that should have been done). Not every unsafe act produces an injury or a loss, but by definition it has the potential for producing an accident. A worker may commit unsafe acts regardless of the initial conditions of the work (i.e., whether the condition was safe or unsafe). A few example of unsafe acts are the decision to proceed with work in unsafe condition, disregarding standard safety procedures such as not wearing a hard hat or safety glasses , working while intoxicated, and working with sufficient sleep. Some more examples of unsafe acts are:

- Cleaning, oiling, adjusting, or repairing of moving electrically energized or pressurized equipment

- Failure to use available personal protective equipment (life-saving devices) such as safety helmet or hard hat, safety belt, fall arresters and safety net

- Improper use of equipment

- Taking unsafe positions or postures (under suspended loads, riding on forks of lift trucks, etc.)

- Unsafe placing, mixing, combining etc.

The causes that lead to unsafe acts may include lack of knowledge or skill (unawareness of safe practices, unskilled, improper attitude such as disregard of instruction, etc.), and physical or mental deficiency (defective eyesight or hearing, fatigue, etc.)

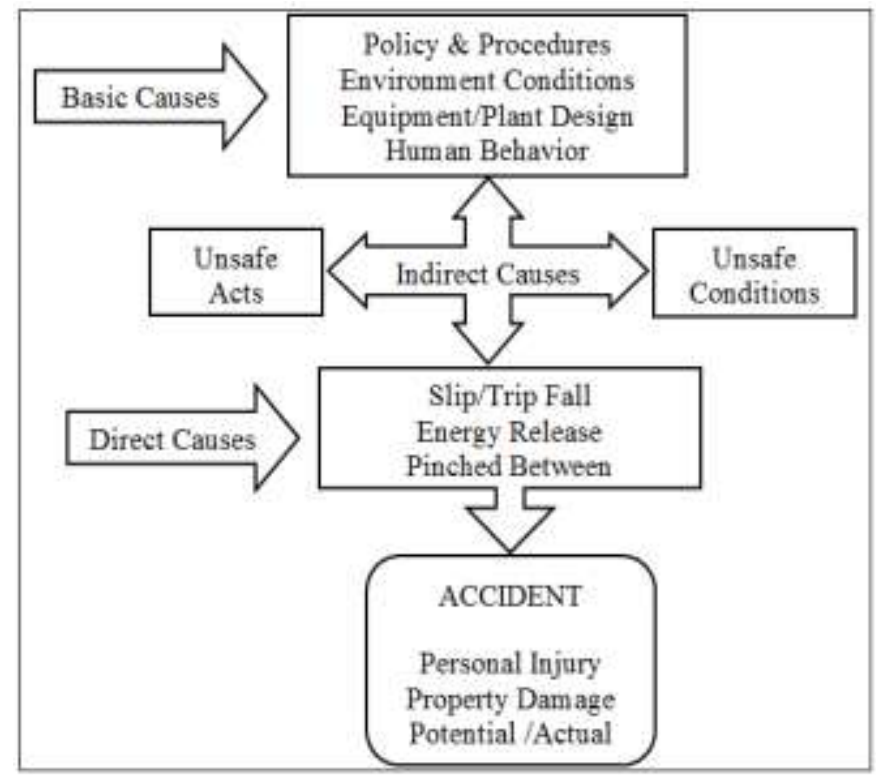

Fig-1: Accident Investigation Levels of Causes [11] 
Principle of Safety

Petersen [12], mentions ten basic principles of safety. These are:

1. An unsafe act, an unsafe condition, and an accident are all symptoms of something wrong in the management system.

2. We can predict that certain sets of circumstances will produce severe injuries. These circumstances can be identified and controlled.

3. Safety should be managed like any other company function. Management should direct the safety effort by setting achievable goals and by planning, organizing and controlling to achieve them.

4. The key to effective line safety performance is management procedures that fix accountability.

5. The function of safety is to locate and define the operational errors that allow accidents to occur. This function can be carried out in two ways:

a. by asking why accidents happen-searching for their root causes

b. by asking whether certain known effective controls are being utilized

6. The causes of unsafe behaviour can be identified and classified. Some of the classifications are - overload (the improper matching of a person's capacity with the load); traps; and the worker's decision to error. Each cause is one that can be controlled.

7. In most cases, unsafe behaviour is normal human behaviour; it is the result of normal people reacting to their environment. Management's job is to change the environment that leads to unsafe behaviour.

8. There are three major subsystems that must be dealt with in building an effective safety system:

a. The physical

b. The managerial

c. The behavioural

d. There are three major subsystems that must be dealt with in building an effective safety system:

9. The safety system should fit the culture of the organization.

10. There is no one right way to achieve safety in an organization; however, for a safety system to be effective, it must meet certain criterions. The system must:

- $\quad$ force supervisory performance

- $\quad$ involve middle management

- have top management visibly showing their commitment

- have employee participation

- be flexible

- be perceived as positive
Many of these principles are just principles without tested techniques available, while other have well-tested methods available [12].

\section{Classification of Accident Causation Factors Proximal and Distal Factor}

The accident causation factors are classified into proximal (immediate causes) and distal (underlying or root causes) factors. Suraji et al., [13], after the analysis of 500 construction accidents in the UK, he clustered the proximal factors into five categories viz, inappropriate construction operation, inappropriate operative actions, inappropriate construction planning, inappropriate construction control and inappropriate site conditions. Distal factors include the project constrains such as project conception and design, selection of the subcontractors, management's influence and organizational and environmental factors.

\section{Immediate and Underlying Causes}

Several local researches have been conducted in tunneling and road projects to identify hazards and causes along with effectiveness. Mishra and Sharestha [14] highlighted the need of safety standard improvement implementation in case of road projects. The researchers from Loughborough University have identified three levels of accident causation including the immediate circumstances, shaping factors and the originating influences $[15,16]$.

Immediate circumstances are easily identifiable and include unsafe acts and unsafe conditions. They can be summarized as; worksite environment such as layout, lighting arrangement and weather conditions, condition and suitability of tools, equipment and materials, adherence to safety rules and capabilities of the construction workers themselves 10 , 17-19]. The shaping factors generally result into the immediate circumstances and include; worker's health condition and fatigue, worksite constructions and housekeeping and level of supervision and communication.

Originating influences (underlying and secondary causes) instigate the shaping factors, and include the client's requirements, economic climate, safety culture, design of structure, risk management system [20, 21], social pressure and failure of the management to anticipate the potential hazards [17].

\section{Organizational Level Factors}

Brace et al., [15], have analyzed the causes of construction accidents through a triangulation strategy comprising of the literature review and industry experts. They have grouped the accident causes in three organizational level categories; macro, mezzo and micro levels. Micro level factors are linked with the human behavior and are quite common on the construction sites, whereas macro and mezzo level factors are generally found at the organizational and 
company level respectively. The causation factors are further divided into four sub-groups workers and work team, workplace, equipment and material [22, 23]. To summarize, the accident causation factors can be divided majorly into four categories viz. management factor, worker related, project related and material and equipment related factors.

\section{Labor Act 2074 (2017) in Nepal}

Under this act, the proprietor shall make the arrangements in the Enterprise as mentioned below.

a) To keep each enterprise clean and tidy by cleaning daily including with germicidal medicines, necessary arrangements of proper drainage and coloring from time to time and preventing from odor.

b) To make arrangements for adequate supply of fresh air and lights as well as proper temperature in the working rooms.

c) To make arrangement of removal and disposal of solid waste during production process.

d) To make arrangements of prevention of accumulation of dust, fume vapor and other impure materials in working rooms which would adversely affect the health.

e) To make arrangements of necessary preventive personal devices for protection of health from adverse any other source and make provisions which would less noise during the work process.

f) To make provision for sufficient supply of pure portable water during the working hours, and to make arrangement for sufficient water in the enterprise where chemical substances are used or produced which may be injurious to health for the purpose of extinguishing fire or wash and cleaning during emergency situation.

g) To conduct compulsory health check-ups of the workers or employees once a year where the nature of works is likely to affect the health adversely.

h) Protection of Eyes: The necessary protective means shall have to be arranged for the protection of eyes of all the workers and employees from injuries likely to be caused by dust or pieces while working using glass, mercury, magnet, pallets, iron, concrete, cement, lime, stone and explosive substances.

i) Necessary protective devices shall have to be arranged to protect the eyes from harmful rays coming from during the process of welding or gascutting or other similar works.

j) Protection from Chemical Substance: The Proprietor shall have to make provision for necessary personal protective devices for the protection of workers or employees handling chemical substances.

k) Provision for Safety against Fire: The Proprietor shall have to make arrangements of necessary modern equipment for safety against fire in each site. Provision shall have to be made for exit from enterprise during emergency. Other provisions to be made in relation to safety from fire including fire-fighting devices shall be as prescribed.

1) Hazardous Machines to be fenced: strong fences shall have to be placed around every part of hazardous machines, instruments and equipment operated by energy. In case it is required to do inspecting, lubrication or adjusting any part of hazardous machines during its running condition only experienced and well-trained adult worker or employee shall have to be engaged to perform such works.

m) Orders to Provide for safety: In the situation where provision of safety has not been made which was required to be done pursuant to the Act, the Labor Officer may issue a written order giving a reasonable time limit in order to provide and make necessary arrangements thereon within such period. If the order issued has not been followed, the Labor Officer may order the closure of such unsafe portion, plant or machinery or enterprise and it shall be duty of the enterprise to abide by such order.

n) Notice to be provided: Each Enterprise shall have to inform the Labor Office within three days if any worker or employees dies or is injured making him/her disabled to work for more than forty eight hours, from an accident occurred or for any other reason, and within seven days if such workers or employees has been caught by any disease resulting from the profession.

- Provision of construction tools: The proprietor shall have to avail from its own idea all necessary tools and materials in sufficient quantity for the workers engaged in the construction work at construction site.

- Special Arrangement at Temporary construction sites: At temporary construction site where fifty or more workers are engaged, the proprietor shall make arrangement for quarters, food, drinking water etc. for the workers who do not have residence nearby.

- Accident Insurance: The proprietor shall have to insure all workers engaged in the construction site against accident in the way as prescribed.

- Safety Arrangement: The Personal Protective Equipment (PPE) necessary for the workers engaged in construction works must be provided. The proprietor shall make necessary and adequate arrangement of safety at the sites of construction works.

- Compensation: In case any worker or employee of the Enterprise is physically wounded or seriously hurt or dies in course of his/her work, the compensation shall be paid to him/her or to his/her family, as prescribed.

\section{National Building Code Nepal}

National Building Code (2064) is specially prepared for construction safety in building 
construction works. It has tried to include basic standards. The main purpose of these standards is to provide reasonable degree of safety to construction related personnel in building construction work. The basic concepts used in deriving these standards are based on those of the national building code of India and the relevant Indian safety standards there in, and the Health and Safety at work Act of United Kingdom (UK). The provisions of this standard are the minimum requirements that are to be adopted during building and other civil construction or demolition work.

Clauses 3 to 17 - the minimum requirements that are to be adopted for the safety and health of workers.

Clause 3 - the safety standards against storage and handling of hazardous materials.

clause 4 - The first aid facility shall be maintained with at least a para-medical health worker.

clause 5 - The adequate firefighting equipment and fire escapes shall be provided as required by Nepal fire safety standard.

Clause 6 - the provision of personal protective equipment. The workers shall be provided with hard hats to protect from falling materials and safety goggles and mask shall be provided to workers who are working in dusty area. Similarly, safety boots shall be provided when workers have to work in area where piercing objects are encountered and safety belts when workers have to work in heights.

Clause 7 and 8 - the standard for safety in excavation and foundation work. Escape route, oxygen mask, protection of wall of trench and adequate barriers shall be provided during excavation work. Adequate measures shall be taken against collapses of wall of excavations e.g. shoring.

Clause 11 - It describes that all electrical wires laid over floor during construction shall be covered to protect them from moving machinery and personnel. While construction is undertaken close to exposed high- or low-tension lines, all such cables shall be covered with insulation so as to avoid electrocutions. All the electrical work shall be carried out by qualified electrician.

Clause 12 - temporary work such as false works and formworks shall be securely tied to the permanent structures.

Clause 16 - Labor shall be provided with drinking water, adequate and safe shelter, toilet facilities, safety clothing and free from combustible materials or hazardous chemicals.

According to 16 - all workers shall be insured by their employer against accidents in the workplace. The minimum cover for accidental death shall be two hundred thousand Nepalese Rupees per worker. For the other accidents, the minimum cover shall be as that currently determined by the National Insurance Company of Nepal.

Clause 17 - the safety requirements such as proper operation of construction and transportation equipment, installation of safety nets, control and restriction of entry of third person into the site.

\section{Description of Research area with map}

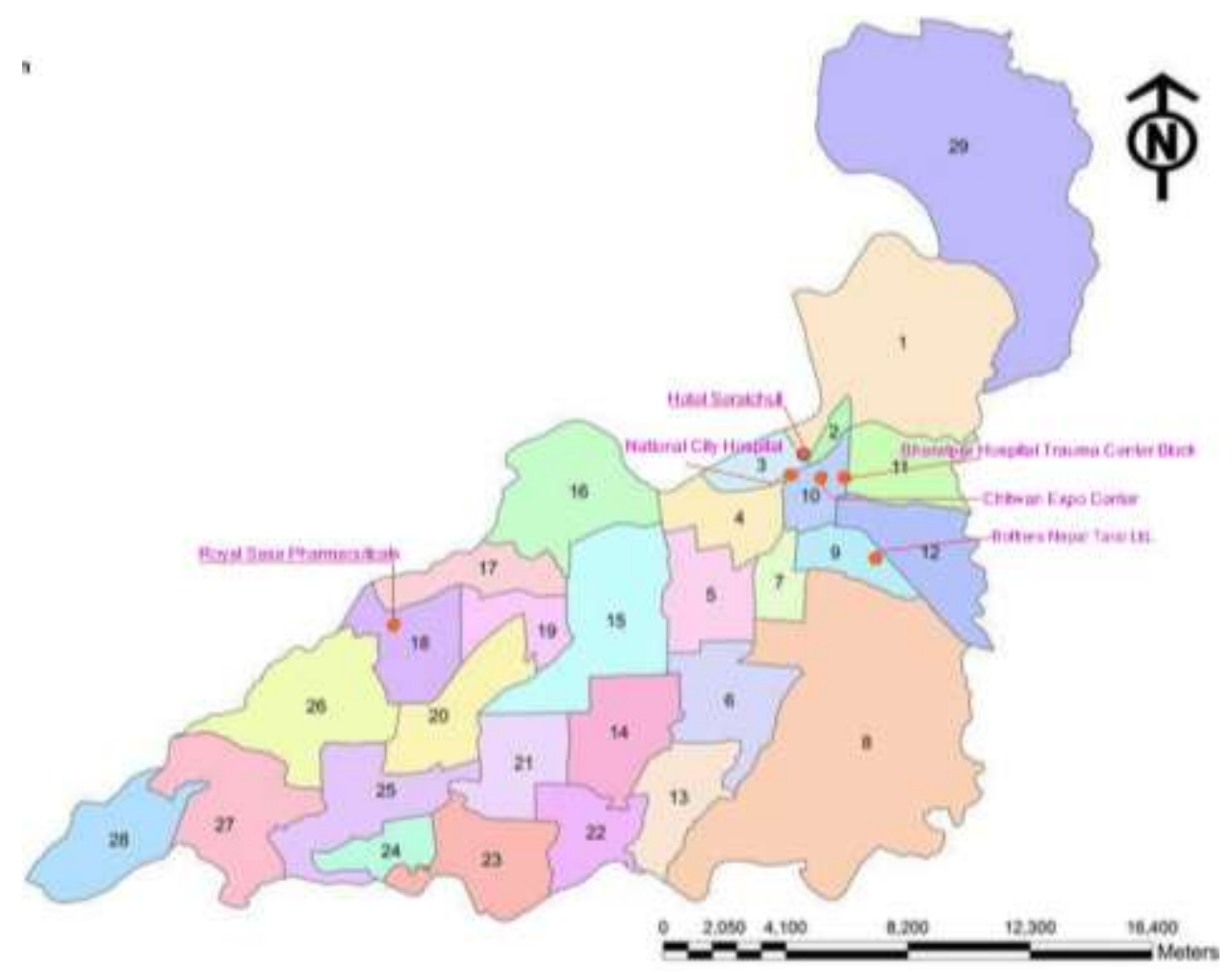

Fig-2: Bharatpur Metropolitan City spotting Research Area 
The study is focused in Bharatpur Metropolitan City. 5 different commercial buildings with varying purposes shall be studied. All the buildings taken for the study are in the stage of under construction phase through to completion phase. Short descriptions of projects that shall be studied are summarized as below:

Table-1: Research Area Description

\begin{tabular}{|l|l|l|}
\hline Project Name & Factory Building of Royal Sasa Pharmacuticals & Avg. Nos of Workers \\
\hline Project Location & Bharatpur-19, Chitwan & 25 \\
\hline Client & Royal Sasa Pharmacuticals Pvt. Ltd. & \\
\hline Contractor & Krishna Construction & \\
\hline Project Cost & 30 crores & \\
\hline Project Name & Hotel Siraichuli & 75 \\
\hline Project Location & Bharatpur-10, Chitwan & \\
\hline Client & Hotel Saraichuli Pvt. Ltd. & \\
\hline Contractor & Religare Construction & \\
\hline Project Cost & 70 crores & \\
\hline Project Name & Chitwan Expo Center & 40 \\
\hline Project Location & Bharatpur-10, Chitwan & \\
\hline Client & Chitwan Udhyog Sangh & \\
\hline Contractor & Om Satya Sai Construction/ Asish-Om Satya Sai JV & \\
\hline Project Cost & 41 crores 46 lakhs & 80 \\
\hline Project Name & National City Hospital & \\
\hline Project Location & Bharatpur-10, Chitwan & \\
\hline Client & National City Hospital Pvt. Ltd. & \\
\hline Contractor & Shine builders \& Engineering construction Pvt.Ltd & \\
\hline Project Cost & 15 crores Eightl lakhs & \\
\hline Project Name & Construction of Diagnostic \& Trauma Center (Block C) & \\
\hline Project Location & Bharatpur-10, Chitwan & \\
\hline Client & Bharatpur Hospital & \\
\hline Contractor & Ashish/ Shyamsundar/ Pratistha J/V & \\
\hline Project Cost & 28 crores & \\
\hline
\end{tabular}

\section{Questionnaire Survey}

After the validity of the questionnaire, the questionnaire was distributed to the respondent of the consultant and the contractor's Managers/Officers/Engineers. The entire questionnaire was distributed by visiting them. Likert Scale is used in the questionnaire where respondents specify their level of agreement or disagreement on a symmetric agreedisagree scale for a series of statements.

\section{Relative Importance Index (RII)}

The Relative Importance Index (RII) of determination of significance of factors was adopted because, Adnan et al., 2007 [24] as cited in Mishra [3], asserted that to analyze data on ordinal scale (e.g. Likert scale 1-5), the application of Relative Importance Index is also suitable. The Relative Importance Index is computed as in [24]:
Relative Importance Index $=\frac{\sum w}{A N}=\frac{5 n 5+4 n 4+3 n 3+2 n 2+n 1}{5(n+n 2+n 3+n 4+n 5)} * 100$

Where:

n1 - number of respondents who answered "not important"; n2 - number of respondents who answered "not important"; n3- number of respondents who answered "neutral "; n4 - number of respondents who answered "important"; n5 - number of respondents who answered "very important"

It is worthwhile to note that the nearer the value of importance index of the identified factor is unity (1) or $100 \%$, the more significant it is and hence, a greater impact on the rest of the variables.

\section{RESULTS AND DISCUSSION}

Factor causing accident in construction industry

Different factors were identified from literature were surveyed as follow. 


\section{Accident factors attributed to management}

Table-2: Accidental Factors attributed to the Management

\begin{tabular}{|l|l|l|l|l|l|l|l|}
\hline S. No & Factors * I stands for Important & Very I. & Important & Moderate & Less I. & Not I. & RII \\
\hline 1 & $\begin{array}{l}\text { No compliance to governmental safety rules and } \\
\text { regulation }\end{array}$ & 43 & 24 & 5 & 7 & 4 & 0.829 \\
\hline 2 & $\begin{array}{l}\text { Appropriate Personal Safety procedures were not } \\
\text { specified }\end{array}$ & 32 & 23 & 12 & 8 & 8 & 0.752 \\
\hline 3 & No training program for the workers & 29 & 18 & 21 & 12 & 3 & 0.739 \\
\hline 4 & $\begin{array}{l}\text { Not use of the correct tools/equipment for the } \\
\text { specific task }\end{array}$ & 22 & 19 & 16 & 22 & 4 & 0.679 \\
\hline 5 & $\begin{array}{l}\text { Lack of supervision and control on workers to } \\
\text { wear safety items }\end{array}$ & 25 & 12 & 32 & 14 & - & 0.715 \\
\hline 6 & Not enough rest time during the task & 16 & 22 & 20 & 17 & 8 & 0.65 \\
\hline 7 & No cohesiveness among the job crew & 9 & 30 & 18 & 22 & 4 & 0.644 \\
\hline 8 & $\begin{array}{l}\text { Management pushing work beyond workers } \\
\text { abilities }\end{array}$ & 19 & 6 & 13 & 20 & 23 & 0.533 \\
\hline 9 & No safety engineers at site & 6 & 13 & 25 & 11 & 28 & 0.499 \\
\hline 10 & $\begin{array}{l}\text { Lack of appreciation after the competition of the } \\
\text { task }\end{array}$ & - & 21 & 28 & 5 & 26 & 0.492 \\
\hline 11 & Lack of weekly safety meeting & 10 & 5 & 9 & 39 & 20 & 0.469 \\
\hline 12 & Mismanagement of working schedule & 9 & 6 & 20 & 15 & 33 & 0.462 \\
\hline 13 & Lack of resources of petty contractor & 11 & 3 & 5 & 26 & 38 & 0.422 \\
\hline 14 & No written/known procedure for the assigned job & 4 & 5 & 12 & 36 & 26 & 0.419 \\
\hline
\end{tabular}

According to the Table-2, factor of accident related to the management, not compliance of the government rules and regulation at the site is the prior one with the significant relative importance index score of 0.829 . The other factor viz appropriate personal safety procedure to be followed in construction, the lack of the training programs to the workers, not use of the correct tools/ equipment for the specific task and lack of supervision and control on workers to wear safety items were also the important to avoid the construction accidents. As per the respondents (KII) not enough time of rest during the task, no cohesiveness among the job crew were also the less but important factor causing the accidents. The other factors like the lack of the safety engineers in the site, lack of the appreciation after the completion of the task, lack of the safety meetings, mismanagement of the working schedule, lack of the resource of the petty contractors and lack of the written procedures for the assigned job were the least significant factor causing workplace accidents.

\section{Accident factors attributed to Workers}

Table-3: Accidental Factors attributed to the Worker

\begin{tabular}{|l|l|l|l|l|l|l|l|}
\hline S. No & Factors & Very I. & Important & Moderate & Less I. & Not I. & RII \\
\hline 1 & Negligent in wearing personal protection items & 33 & 19 & 31 & - & - & 0.805 \\
\hline 2 & Workers was rushing to the work & 29 & 16 & 29 & 7 & - & 0.780 \\
\hline 3 & Overconfidence of the worker & 20 & 18 & 10 & 35 & - & 0.656 \\
\hline 4 & The worker's misjudgments & 7 & 21 & 32 & 6 & 16 & 0.586 \\
\hline 5 & Physical fatigue of labor & 8 & 13 & 21 & 46 & 5 & 0.607 \\
\hline 6 & Mental fatigue of the labor & 4 & 11 & 24 & 33 & 11 & 0.513 \\
\hline 7 & Working overtime in the site & 5 & 5 & 17 & 35 & 21 & 0.451 \\
\hline 8 & Lack of knowledge of the personal safety item & 7 & 6 & 28 & 7 & 35 & 0.463 \\
\hline 9 & Unacceptable physical condition of the worker & - & - & 22 & 26 & 35 & 0.369 \\
\hline 10 & $\begin{array}{l}\text { Delaying on the accomplishment of the order by } \\
\text { the labor }\end{array}$ & - & 5 & 38 & 15 & 24 & 0.453 \\
\hline 11 & Worker was suffering from the health problems & - & 8 & 12 & 16 & 42 & 0.342 \\
\hline
\end{tabular}

The accident causation factors related to the workers was presented in the Table-3. As per the interviewee, the workers negligent in wearing the safety items can increase the accident occurrence. In the site the accident also can occur sometimes due to workers rushing to the work, overconfidence of the workers and physical fatigue of the workers. The other minor factor causing accident include misjudgment of the workers during the work, mental fatigue, overtime work, lack of the knowledge of the personal safety item, usage of unacceptable physical condition of the workers, delay of order and worker suffering from the health problems. 


\section{Factors attributed to Projects}

Table-4: Accidental Factors attributed to the Project

\begin{tabular}{|l|l|l|l|l|l|l|l|}
\hline S. No & Factors & Very I. & Important & Moderate & Less I. & Not I. & RII \\
\hline 1 & Lack of working space and site layout & 30 & 28 & 7 & 6 & 7 & 0.723 \\
\hline 2 & Weather conditions were extreme & 18 & 7 & 45 & 13 & 15 & 0.708 \\
\hline 3 & $\begin{array}{l}\text { Unsuitable living housing and } \\
\text { transportation facilities of workers }\end{array}$ & 18 & 14 & 19 & 15 & 5 & 0.574 \\
\hline 4 & Job or task was too difficult to perform & 6 & 18 & 15 & 27 & 19 & 0.53 \\
\hline 5 & Local hazard makes task difficult & - & 10 & 6 & 44 & 22 & 0.405 \\
\hline
\end{tabular}

The third accident causation factor related to the project is presented in the Table-4. According to the response of the KII, the lack of the work space and improper site layout is also the prior aspect for being accident. The work during the extreme weather condition also causes the accident frequently. The supplementary aspect are the unsuitable living housing condition and transportation facility for the workers, difficulty of job or the task and the local hazard makes the task difficult.

\section{Factors attributed to Equipment}

Table-5: Accidental Factors attributed to Equipment

\begin{tabular}{|l|l|l|l|l|l|l|l|}
\hline S. No & Factors & Very I. & Important & Moderate & Less I. & Not I. & RII \\
\hline 1 & Condition of equipment & 29 & 26 & 15 & 5 & 8 & 0.752 \\
\hline 2 & Lack of proper housekeeping & 19 & 8 & 40 & 6 & 10 & 0.648 \\
\hline 3 & $\begin{array}{l}\text { Design and Specs of Equipment's for } \\
\text { specific task }\end{array}$ & 9 & 18 & 26 & 14 & 18 & 0.581 \\
\hline 4 & Supply and availability of equipment & 13 & 6 & 24 & 8 & 30 & 0.499 \\
\hline
\end{tabular}

Another causation factors for the accident, related to the equipment used in the field is shown in the table above. The most prior sub-factor is the use of the bad condition equipment in the construction site. As per the respondents the other minor factor includes lack of the proper housekeeping, the design and specs of the equipment was not as per the task and the improper supply and availability of the equipment.

The study has prioritized thirty-four contributory factors of the accident causation through a dual team of the engineers encompassing the semistructured interviews with the experts, review of the previous studies too. A reasonable consensus was achieved among the two groups of consultant and contractors. The tests include the Relative Important Index and the Spearman's rank correlation test. The three most significant factors no compliance to the governmental safety rules and regulation, worker negligent in use of the personal protective items and workers rushing to the work were graded best among the 34 provided items.
Initially the consultant team give prior focus to the not compliance to the government safety rules and regulations, worker rushing to the works and overconfidence of the workers as it implies accident causation factor attributed to the organizational level and workers only. Later ranking was provided to the no use of the appropriate personal safety procedures, condition of the equipment, lack of the site planning and layout, no training for the workers, lack of supervision and control on workers to wear safety items, overconfidence of workers and not use of the correct tools for the specific task. Whereas the contractor has prior focus to the worker negligent in wearing personal protective items, workers rushing to the work and no compliance to the government safety rules and regulations. Later ranking was provided to the appropriate personal safety procedures were not specified, worker was rushing to the work, no safety engineer at the site, physical fatigue of the labor, no training program to the workers, lack of the supervision and control on workers to wear the safety items and condition of the equipment. 


\section{Comparison of rank of Contractor and Consultant}

Table-6: Comparison of rank of Contractor and Consultant

\begin{tabular}{|c|c|c|c|c|c|c|c|}
\hline \multirow{2}{*}{$\begin{array}{l}\text { S. } \\
\text { No }\end{array}$} & \multirow[t]{2}{*}{ Factors } & \multicolumn{2}{|c|}{ All Experts } & \multicolumn{2}{|c|}{ All Contractors } & \multicolumn{2}{|c|}{ All consultant } \\
\hline & & RII & Rank & RII & Rank & RII & Rank \\
\hline 1 & No compliance to governmental safety rules and regulation & 0.829 & 1 & 0.785 & 3 & 0.865 & 1 \\
\hline 2 & Appropriate Personal Safety procedures were not specified & 0.752 & 4 & 0.736 & 4 & 0.764 & 4 \\
\hline 3 & No training program for the workers & 0.739 & 6 & 0.701 & 8 & 0.756 & 7 \\
\hline 4 & Not use of the correct tools/equipment for the specific task & 0.679 & 10 & 0.645 & 13 & 0.748 & 10 \\
\hline 5 & $\begin{array}{l}\text { Lack of supervision and control on workers to wear safety } \\
\text { items }\end{array}$ & 0.715 & 8 & 0.688 & 9 & 0.756 & 8 \\
\hline 6 & Not enough rest time during the task & 0.65 & 12 & 0.648 & 11 & 0.668 & 13 \\
\hline 7 & No cohesiveness among the job crew & 0.644 & 14 & 0.588 & 16 & 0.658 & 15 \\
\hline 8 & Management pushing work beyond workers abilities & 0.533 & 19 & 0.574 & 18 & 0.425 & 29 \\
\hline 9 & No safety engineers at site & 0.499 & 22 & 0.718 & 6 & 0.325 & 33 \\
\hline 10 & Lack of appreciation after the competition of the task & 0.492 & 24 & 0.498 & 23 & 0.538 & 23 \\
\hline 11 & Lack of weekly safety meeting & 0.469 & 25 & 0.495 & 25 & 0.438 & 24 \\
\hline 12 & Mismanagement of working schedule & 0.462 & 27 & 0.468 & 27 & 0.429 & 26 \\
\hline 13 & Lack of resources of petty contractor & 0.422 & 30 & 0.508 & 21 & 0.429 & 25 \\
\hline 14 & No written/known procedure for the assigned job & 0.419 & 31 & 0.458 & 28 & 0.428 & 27 \\
\hline 15 & Workers Negligent in wearing personal protection items & 0.805 & 2 & 0.81 & 1 & 0.799 & 2 \\
\hline 16 & Workers was rushing to the work & 0.78 & 3 & 0.728 & 5 & 0.786 & 3 \\
\hline 17 & Overconfidence of the worker & 0.656 & 11 & 0.648 & 12 & 0.748 & 9 \\
\hline 18 & The accident occurred due to the worker's misjudgments & 0.586 & 16 & 0.588 & 15 & 0.658 & 16 \\
\hline 19 & Physical fatigue of labor & 0.607 & 15 & 0.705 & 7 & 0.425 & 29 \\
\hline 20 & Mental fatigue of the labor & 0.513 & 21 & 0.403 & 34 & 0.675 & 12 \\
\hline 21 & Working overtime in the site & 0.451 & 29 & 0.57 & 19 & 0.385 & 31 \\
\hline 22 & Lack of knowledge of the personal safety item & 0.463 & 26 & 0.495 & 24 & 0.427 & 28 \\
\hline 23 & Unacceptable physical condition of the worker & 0.369 & 33 & 0.408 & 33 & 0.345 & 32 \\
\hline 24 & Delaying on the accomplishment of the order by the labor & 0.453 & 28 & 0.416 & 32 & 0.576 & 19 \\
\hline 25 & Worker was suffering from the health problems & 0.342 & 24 & 0.451 & 29 & 0.423 & 30 \\
\hline 26 & Lack of working space and site layout & 0.723 & 7 & 0.625 & 14 & 0.764 & 6 \\
\hline 27 & Weather conditions were extreme & 0.708 & 9 & 0.288 & 17 & 0.748 & 11 \\
\hline 28 & $\begin{array}{l}\text { Unsuitable living housing and transportation facilities of } \\
\text { workers }\end{array}$ & 0.574 & 18 & 0.515 & 20 & 0.642 & 17 \\
\hline 29 & Job or task was too difficult to perform & 0.53 & 20 & 0.505 & 22 & 0.564 & 21 \\
\hline 30 & Local hazard makes task difficult & 0.405 & 32 & 0.432 & 30 & 0.325 & 34 \\
\hline 31 & Condition of equipment & 0.752 & 5 & 0.657 & 10 & 0.759 & 5 \\
\hline 32 & Lack of proper housekeeping & 0.648 & 13 & 0.804 & 2 & 0.664 & 14 \\
\hline 33 & Design and Specs of Equipment's for specific task & 0.581 & 17 & 0.495 & 26 & 0.586 & 18 \\
\hline 34 & Supply and availability of equipment & 0.499 & 23 & 0.428 & 31 & 0.574 & 20 \\
\hline
\end{tabular}

For the Spearman's Rank Correlation Coefficient: -Difference in the rank $(\mathrm{d})=$ Rank by Contractor - Rank by the Consultant, by the formula,

Spearman's Rank Correlation Coefficient $=1-\frac{6 \Sigma d^{2}}{n^{3}-n}=1-\frac{6 \times 1172^{2}}{34^{3}-34}=0.82$

Both the client and the contractor team agree on no compliance to the government safety rules and regulation is the prior factor for accident causation. In the previous study by Maharjan S [25], he found out that enforcement status of rules and regulation at commercialcomplex construction site was not satisfactory. He further details that the labor was unknown about the Labor Act and Regulations. Thus, in our context, there is poor implementation of the rules and regulation by the contractor, consultant and worker teams too. Workers is negligent in wearing personal protective items during the construction activities. According to Health and Safety Executive (HSE) and OSHA, the expatriate workers are at increased risk from safety and health point of view. The main reasons cited for this are languages and communication problems (85\% of cases), being new to job, cultural factors also feature. Despite this, 50\% of employers do nothing different for migrant worker health and safety than they do for other workers (HSE). Furthermore, the quick and easiness in the work make them to avoid the PPE. Worker also do rush to the work for showing overconfidence and quickness. This is another factor for accident causation. In our working fields, for each task appropriate personal safety procedure are not specified. Due to ignorance and illiteracy too, the mishaps occur from time to time. 
After the ranking, the spearman's rank correlation coefficient is used to discover the strength of a link between two sets of data. As the value of correlation is strongly positive so there is strong connection between the dual team data.

\section{Responsible Parties for accident in Site}

About $70 \%$ employer responded that workers is the major responsible party for the accidents followed by the $22 \%$ due to the fault of the contractor. About $7 \%$ employer responded as consultant as the responsible party for the accidents.

\section{Preventive and Control Measure Implement}

The preventive measure that can be applied for the prevention of the accidents. As shown in the given figure, about $90 \%$ of the respondents responded that safety meeting before and after the task is the leading preventive measure that can be used at the site. About $65 \%$ of the KII responded that the proper housekeeping in the construction project site can reduce the accidents. The proper and efficient use of the sign and signals and training for the workers and the engineering team were third and fourth respectively with $51 \%$ and $46 \%$. The safety orientation to the workers and efficient use of the safety policy of construction in site were responded to $40 \%$ and $28 \%$ approximately.

It was observed that the safety meeting and sign and signals were the prior factors to be considered as the preventive measure for the accident in the housing construction sites. Another measure like proper housekeeping and safety training also need to be given to the work force. The administrative implementing factors like safety policy and orientation and awareness also needed to be provided efficiently.

\section{Control Measure can used to prevent accident}

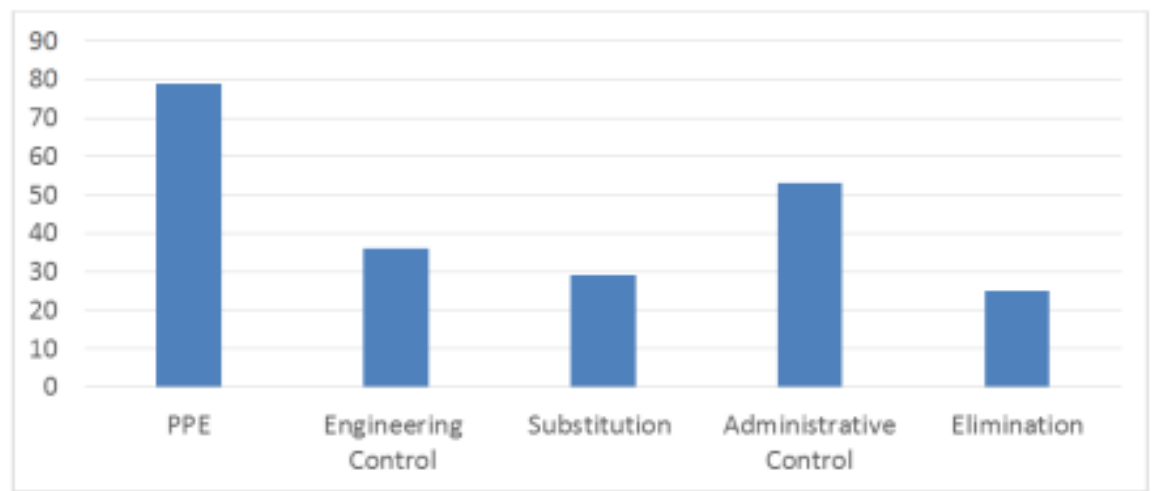

Fig-3: Control Measure to Prevent Accident

Figure-3 demonstrate the result of the control measure can be used to control accidents. About $95 \%$ of the KII responded that PPE is the prior control method for the accident. The administrative control is responded by $63 \%$ as efficient control measure. The other minor factors include like engineering control, substitution and elimination include $43 \%, 34 \%$ and $30 \%$ respectively. As Mishra et al., [26] highlighted even in hydropower tunneling to improve the effectiveness. It is a systematic step by step process used in workplaces to minimize or reduce exposure to hazards. The best way to control a hazard is to eliminate it and remove the danger. The second best way to control a hazard is to substitute something else in its place that would be non-hazardous or less hazardous to workers if a hazard can't be eliminated, isolated, or substituted; the next best approach is to use engineering controls. If engineering controls cannot be implemented, move on to considering administrative controls. Personal protective equipment is the least effective way to prevent accidents. PPE should be used only while other more effective controls are being developed or installed, or if there are no other more effective ways to control the hazard [14].

\section{CONCLUSION}

Some of the conclusions are drawn

The causation factor attribute to organizational level were identified as major one. No compliance to governmental safety rules and regulation, Workers Negligent in wearing personal protection items, Lack of working space and site layout, Condition of equipment, Workers was rushing to the work and Appropriate Personal Safety procedures were not specified were majour factors of accidents. After the ranking, the spearman's rank correlation coefficient is used to discover the strength of a link between two sets of data. As the value of correlation is strongly positive, it means there is strong connection between the dual team data. Workers were Responsible Parties for Accident in Site based on respondent. Most of the respondents responded that safety meeting before and after the task is the leading preventive measure that can be used at the site. PPE is the prior control method for the accident as per respondent where as elimination is least prioritized which is due to lack of knowledge as elimination, substitution, engineering control, administrative control followed by PPE as last line of control should be practiced. It means we need knowledge of among workers to professional is most. 
The housing safety management in the project was inferior to the anticipated codes and byelaws. Some of the accident causation factor from the literature review also coincides with the risk and hazards in the housing construction.

\section{REFERENCES}

1. World Health Organization. (2001). The World Health Report 2001: Mental health: new understanding, new hope. World Health Organization.

2. National Building Code (NBC114: 1994).

3. Mishra, A. K. (2018). Assessment of Human Resource Capacity of Construction Companies in Nepal. J Adv Res Jour Mass Comm, 5(4):14-25.

4. Maskey, A., \& Mishra, A. K. (2018). Labor productivity assessment of armed police force Nepal building construction projects. International Journal of Current Research, 10(11).

5. Central Bureau of Statistics. (2019). National Economic Census 2018. Kathmandu: Central Bureau of Statistics.

6. Laufer, A., \& Tucker, R. L. (1987). Is construction project planning really doing its job? A critical examination of focus, role and process. Construction Management and Economics, 5(3), 243-266.

7. Kartam, N. A. (1997). Integrating safety and health performance into construction CPM. Journal of Construction Engineering and Management, 123(2), 121-126.

8. Khanal, S., Attallah, N., Smith, D. E., KlineRogers, E., Share, D., O’Donnell, M. J., \& Moscucci, M. (2005). Statin therapy reduces contrast-induced nephropathy: an analysis of contemporary percutaneous interventions. The American journal of medicine, 118(8), 843-849.

9. Ritz G. Total Construction Project Management [Book]. - New York : McGraw-Hill, 1994.

10. Abdelhamid, T. S., \& Everett, J. G. (2000). Identifying root causes of construction accidents. Journal of construction engineering and management, 126(1), 52-60.

11. Jamela [Online] // https://www.slideshare.net/Jamela/ohs-accidents. Jamela.

12. Petersen, D. (1989). Techniques of Safety Management [Book]. - [s.1.] : McGraw-Hill.

13. Suraji, A., Duff, A. R., \& Peckitt, S. J. (2001). Development of causal model of constructionaccident causation. Journal of Construction Engineering and Management, 127(4):337-344.

14. Mishra, A. K., \& Shrestha, M. (2017). Health and Safety Status of Casual Workers in Road
Improvement Project Kathmandu Valley, Nepal. International Journal of Engineering Technology Science and Research (IJETSR); 4(9): ISSN 2394 3386 www.ijetsr.com.

15. Brace, C., Gibb, A., Pendlebury, M., \& Bust, P. (2009). Health and Safety in the Construction Industry: Underlying Causes of Construction Fatal Accidents - External Research, Phase 2 Report, Loughborough,

from:http://www.hse.gov.uk/construction/resource s/phase2ext.pdf (accessed 21 December 2018)

16. Health \& Safety Executive (HSE), UK, 1974.

17. Ali, T. H., \& Mohamed, S. (2010). National cultural orientations and site managers' preferences in Pakistan", Second International Conference on Construction in Developing Countries (ICCIDC-II). Advancing and Integrating Construction Education, Research and Practice, 35 August, Cairo, 836-844.

18. Hamid, A. R. A., Majid, A., \& Singh, B. (2008). Causes of accidents at construction sites. Malaysian Journal of Civil Engineering, 20(2):242-259.

19. Holt, A. S. J. (2008). Principles of Construction Safety, John Wiley \& Sons, available at: http://goo.gl/DAFpIA (accessed 1 February 2018)

20. HSE. (2003). Causal Factors in Construction Accidents, Research Report 156, Leicestershire, available

http://www.hse.gov.uk/research/rrpdf/rr156.pdf (accessed 25 December 2018)

21. Lingard, H., Cooke, T., \& Blismas, N. (2011). Coworkers' response to occupational health and safety. Engineering, Construction and Architectural Management, 18(2):159-175.

22. Manu, P. A., Ankrah, N. A., Proverbs, D. G., \& Suresh, S. (2010). An approach for determining the extent of contribution of construction project features to accident causation. Safety Science, 48(6):687-692.

23. Swuste, P., Frijters, A., \& Guldenmund, F. (2012). Is it possible to influence safety in thebuilding sector? A literature review extending from 1980 until the present. Safety Science, 50(5):1333-1343.

24. Adnan, H. (2007). Yentirizal. 2007. Blessing or.

25. Maharjan, S., Zhu, Q., Zhang, Y., Gjessing, S., \& Basar, T. (2013). Dependable demand response management in the smart grid: A Stackelberg game approach. IEEE Transactions on Smart Grid, 4(1), 120-132.

26. Mishra, A. K., Lama, C., Sah, D. P., \& Badagha, D. G. (2019). Effectiveness of Safety Measures Implementation. Journal of Advanced Research in Civil Engineering and Environmental Engineering, 6(2), 1-20. 